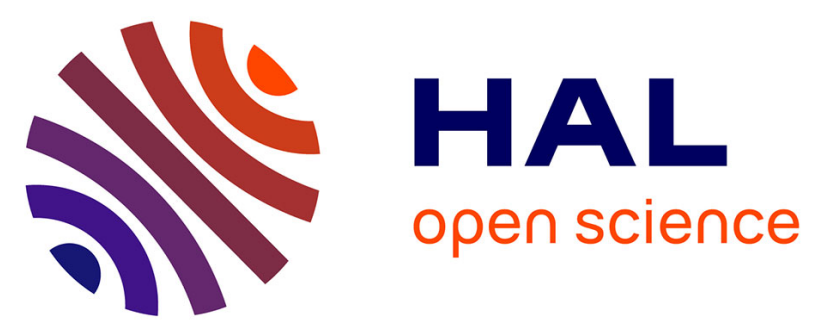

\title{
New glucosyloxybenzyl 2R-benzylmalate derivatives from the undergrounds parts of Arundina graminifolia (Orchidaceae).
}

Florence Auberon, Opeyemi Joshua Olatunji, Pierre Waffo-Téguo, Ademola

Ezekiel Adekoya, Frédéric Bonté, Jean-Michel Merillon, Annelise Lobstein

\section{To cite this version:}

Florence Auberon, Opeyemi Joshua Olatunji, Pierre Waffo-Téguo, Ademola Ezekiel Adekoya, Frédéric Bonté, et al.. New glucosyloxybenzyl 2R-benzylmalate derivatives from the undergrounds parts of Arundina graminifolia (Orchidaceae).. Fitoterapia, 2019, 135, pp.33-43. 10.1016/j.fitote.2019.03.030 . hal-02623591

\section{HAL Id: hal-02623591 \\ https://hal.inrae.fr/hal-02623591}

Submitted on 22 Oct 2021

HAL is a multi-disciplinary open access archive for the deposit and dissemination of scientific research documents, whether they are published or not. The documents may come from teaching and research institutions in France or abroad, or from public or private research centers.
L'archive ouverte pluridisciplinaire HAL, est destinée au dépôt et à la diffusion de documents scientifiques de niveau recherche, publiés ou non, émanant des établissements d'enseignement et de recherche français ou étrangers, des laboratoires publics ou privés.

\section{(ㅇ)(1) $\$$}

Distributed under a Creative Commons Attribution - NonCommerciall 4.0 International 


\section{New glucosyloxybenzyl $2 R$-benzylmalate derivatives from the}

\section{2 undergrounds parts of Arundina graminifolia (Orchidaceae)}

3 Florence Auberon ${ }^{\mathrm{a}} *$, Opeyemi Joshua Olatunji ${ }^{\mathrm{b}}$, Pierre Waffo-Teguo ${ }^{\mathrm{c}}$, Ademola Ezekiel Adekoya ${ }^{\mathrm{b}}$,

4 Frédéric Bonté ${ }^{\mathrm{d}}$, Jean- Mérillon ${ }^{\mathrm{c}}$, Annelise Lobstein ${ }^{\mathrm{a}}$

5 a Strasbourg University, Faculty Michel of Pharmacy, UMR 7200, 67400 Illkirch-Graffenstaden,

6 France

$7 \quad{ }^{b}$ Faculty of Traditional Thai Medicine, Prince of Songkla University, Hat Yai, 90112, Thailand.

$8{ }^{c}$ Bordeaux University, Faculty of Pharmacy, ISVV, EA 4577, USC 1366 INRA, 33400 Villenave

9 d'Ornon Cedex, France

$10 \quad{ }^{\mathrm{d}}$ LVMH Recherche, 45800 Saint Jean de Braye, France

11

17 *Corresponding author: Laboratory of Pharmacognosy and Bioactive Natural Products, Faculty of 18 Pharmacy, University of Strasbourg, 67400 Illkirch-Graffenstaden, France 
1 Abstract

Phytochemical investigation of the underground part of the blossoming tropical orchid

3 Arundina graminifolia led to the isolation of six new glucosyloxybenzyl $2 R$-benzylmalate derivatives

4 named arundinosides L-Q (1-6) together with 5 known compounds arundinosides D-F, J and K (7-11).

5 The structures of the isolated compounds were determined by extensive spectroscopic data analysis.

6 The anti- $\alpha$-glucosidase and antioxidant activities of the isolated compounds were determined. The

7 result indicated that compounds 4-6 and $\mathbf{9}$ showed moderate to weak $\alpha$-glucosidase inhibitory effects

8 as well as moderate antioxidant effect.

9

10

11

12

13

14

15

16 Keywords: Arundina graminifolia, Orchidaceae, glucosyloxybenzyl $2 R$-benzylmalate derivatives,

17 arundinosides L-Q 


\section{Introduction}

The family Orchidaceae is a diverse and widely spread family of flowering plant with approximately 28,000 identified species which is spread across 800 genera [1]. Among these, Arundina graminifolia (D. Don) Hochr. popularly known as bamboo is a well-known specie in the family Orchidaceae. It is used in traditional medicine for treating sore throat, snake bites, food poisoning, jaundice, arthritis, dissipating blood stasis and lung infection [2-4]. It is native to the subtropical Asian countries of Thailand, India, Nepal, Malaysia, Singapore, China, Indonesia, Sri Lanka, Vietnam and Philippines [5-10]. To date, a number of secondary metabolites, such as stilbenoids [11, 12], bibenzyls [13, 14], phenanthrenes [15], phenolics [16-18], fluorenones [19] and glucosyloxybenzyl-2-benzylmalate derivatives [20, 21] have been characterized from A. graminifolia. Although A. graminifolia have been proven to be a reservoir of structurally diverse molecules, only two reports have structurally characterized glucosyloxybenzyl-2-benzylmalate derivatives from this species [20-21]. We previously reported two new stilbenoids and seven new glucosyloxybenzyl-2Rbenzylmalate derivatives from the aerial part of the plant [20, 22]. Motivated by a search for additional new metabolites from the plants, we thus investigated the chemical components from the underground parts of A. graminifolia. As a result, six new structurally related glucosyloxybenzyl $2 R$-benzylmalate derivatives named arundinosides L-Q (1-6) along with five known compounds arundinosides D-F, J and $\mathrm{K}$ (7-11) were isolated and identified. We herein report the details of isolation and structural elucidation of the compounds.

\section{Experimental}

\subsection{General experimental procedures}

Optical rotations were measured using a Jasco Perkin Elmer 341 polarimeter (Jasco, Lisses, France). UV spectra were recorded on a Shimadzu UV-2401 PC spectrometer (Shimadzu, Kyoto, Japan). IR spectra were recorded on a 380 FT-IR spectrophotometer (Thermo Electron Corporation, Saint Herblain, France). 1D and 2D NMR spectra were obtained using a Bruker $500 \mathrm{MHz}$ Avance III spectrometer equipped with a DCH ${ }^{13} \mathrm{C} /{ }^{1} \mathrm{H}$ Cryoprobe (Bruker Biospin, Rheinstetten, Germany). HRESI-MS were recorded on a 1200 Agilent Series coupled to an Agilent 6520Accurate Mass Q-TOF 
1 spectrometer (Agilent Technologies, Santa Clara, USA). Gas chromatography analysis was conducted

2 on a Thermo Scientific Trace GS Ultra apparatus (Thermo Electron Corporation, Saint Herblain,

3 France) coupled to an EI-MS detector equipped with a capillaryTR-5MS SQC column $(0.25 \mu \mathrm{m}, 15 \times$

$40.25 \mathrm{~mm}$, Thermo Fischer Scientific) and a DSQII mass spectrometer (Thermo Electron Corporation,

5 Saint Herblain, France). Semi preparative RP-HPLC was performed on a Gilson LC system using a

6 semi preparative Kinetex Axia C-18 Column (100 mm $\times 21.2 \mathrm{~mm}, 5 \mu \mathrm{m}$; Phenomenex, Torrance, CA,

7 USA). Centrifugal partition chromatography was analyzed on a FCPC200 apparatus (Kromaton

8 Technologies, Angers, France) fitted with a rotor made of 20 circular partition disks (1320 partition

9 cells: $0.130 \mathrm{~mL}$ per cell; total column capacity of $1000 \mathrm{~mL}$ ).

\subsection{Plant material}

The plant (A. graminifolia) was obtained from Joe's orchid farm (Chiang Mai Province, Thailand) in September 2010. The dried roots and rhizomes were imported to France in compliance with the requirements of the Convention on International Trade in Endangered Species (CITES). A reference sample with the number $n^{\circ}$ 05-563 was deposited at the herbarium of the Faculty of Science, Chiang Mai University, Thailand.

\subsection{Extraction and isolation}

The air dried undergrounds parts of A. graminifolia $(350 \mathrm{~g})$ were grinded with the help of a Restch ZM 2000 grinder. The obtained powder was exhaustively extracted with ethanol thrice (ratio of $1 \mathrm{~g}$ powder for $20 \mathrm{~mL}$ solvent). The filtrates were combined and evaporated under reduced pressure to afford a crude ethanolic extract (45.63 g). The ethanol extract was then suspended in water and partitioned with $\mathrm{CH}_{2} \mathrm{Cl}_{2}$ and EtOAc to obtain a $\mathrm{CH}_{2} \mathrm{Cl}_{2}$-soluble fraction $(10.40 \mathrm{~g})$ and an EtOAcsoluble fraction (10.93 g). The EtOAc-soluble fraction was separated by Centrifugal Partition Chromatography (CPC) with the solvent system n-heptane/EtOAc/MeOH/ $\mathrm{H}_{2} \mathrm{O}(0.25: 5: 1: 5)$. The rotor was filled to capacity with the organic stationary phase mode without rotating. The aqueous (lower) mobile phase was pumped into the column in the head to tail mode at a flow rate of $5 \mathrm{~mL} / \mathrm{min}$. Then, the rotation speed was increased from 0 to $1000 \mathrm{rpm}$ until complete equilibrium between the 2 phases, giving a dead volume of $350 \mathrm{~mL}$. 
The EtOAc-soluble fraction was separated by two consecutive CPC runs with an average of

$25.0 \mathrm{~g}$ injected in each run. For each run, the sample was dissolved in $40 \mathrm{~mL}$ of the organic/aqueous 3 phase mixture (1:1 v:v). After the injection, the flow rate was gradually increased from $5 \mathrm{~mL} / \mathrm{min}$ to

$411 \mathrm{~mL} / \mathrm{min}$ in $60 \mathrm{~min}$. The flow rate of $11 \mathrm{~mL} / \mathrm{min}$ was maintained for 140 minutes. After $200 \mathrm{~min}$ on an ascending/head to tail mode, an extrusion step of the organic phase was applied at $70 \mathrm{~mL} / \mathrm{min}$ and the rotation speed was decreased to $500 \mathrm{rpm}$. The eluent collected was monitored at 210 and $280 \mathrm{~nm}$ and 14 fractions were obtained in total, twelve in the ascending mode/head to tail (Fractions A-L) and two in the extrusion process (Fractions $\mathrm{M}$ and N).

Fractions B (551 mg), C (863 mg) and D (925 mg) were further fractionated by gel chromatography using Sephadex LH-20 (MeOH). Sub-fraction B-5 (208 mg) was subjected to semipreparative RP-HPLC. The mobile phase consisted of water (A) and acetonitrile (B) both containing $0.05 \%$ formic acid. A gradient of $35 \%$ B for $2 \mathrm{~min}, 35 \%$ to $38 \%$ B in $3 \mathrm{~min}, 38 \%$ to $45 \%$ B in $35 \mathrm{~min}$, $45 \%$ to $50 \%$ B in $5 \mathrm{~min}, 50 \%$ to $100 \%$ B in $5 \mathrm{~min}, 100 \%$ B for 5 minutes at $14 \mathrm{~mL} / \mathrm{min}$ was applied to afford compounds $\mathbf{1}(9.3 \mathrm{mg}), \mathbf{2}(5.0 \mathrm{mg}), \mathbf{3}(4.5 \mathrm{mg}), \mathbf{6}(2.6 \mathrm{mg}), \mathbf{9}(2.8 \mathrm{mg})$ and $\mathbf{1 0}(15.0 \mathrm{mg})$.

Sub-fraction C-3 (130.4 mg) was purified by semi-preparative RP HPLC using the same mobile phase as indicated above to afford compounds $4(4.1 \mathrm{mg}), 5(8.2 \mathrm{mg})$, and $\mathbf{6}(1.2 \mathrm{mg})$. Subfraction D-5 (292.5 mg) was further subjected to semi-preparative RP-HPLC (with 40\% B for 2 min, $40 \%$ to $45 \% \mathrm{~B}$ in $31 \mathrm{~min}, 45 \%$ to $100 \% \mathrm{~B}$ in $10 \mathrm{~min}, 100 \% \mathrm{~B}$ for $5 \mathrm{~min}$ at $14 \mathrm{~mL} / \mathrm{min}$ ) to give compounds $\mathbf{8}(19.8 \mathrm{mg})$ and $\mathbf{1 1}(32.9 \mathrm{mg})$.

\subsubsection{Arundinoside $L(\mathbf{1})$ :}

White amorphous powder $(9.3 \mathrm{mg}) ;[\alpha]_{D}^{25}-56\left(c 0.4, \mathrm{CH}_{3} \mathrm{OH}\right)$; $\mathrm{UV}\left(\mathrm{CH}_{3} \mathrm{OH}\right) \lambda_{\max }(\log \varepsilon): 218$ (3.06), 270 (1.83); IR: 3343, 1720, 1510, 1368, 1233, 1165, 1075, 1034, 826 and $744 \mathrm{~cm}^{-1}$; ${ }^{1} \mathrm{H}$ NMR see Table 1 and ${ }^{13} \mathrm{C}$ NMR see Table 2; HR-ESI-MS: $m / z$, 1169.36070 [M-H]- (calcd. for $\mathrm{C}_{56} \mathrm{H}_{65} \mathrm{O}_{27}$ for 1169.39732).

\subsubsection{Arundinoside $M(\mathbf{2})$ :}

White amorphous powder $(5.0 \mathrm{mg}) ;[\alpha]_{D}^{25}-64\left(c 0.2, \mathrm{CH}_{3} \mathrm{OH}\right) ; \mathrm{UV}\left(\mathrm{CH}_{3} \mathrm{OH}\right) \lambda_{\max }(\log \varepsilon): 217$ (3.13), 269 (1.95), 277 (1.82); IR: 3349, 1720, 1522, 1361, 1243, 1165, 1066, 1030, 826 and $755 \mathrm{~cm}^{-1}$; 
$1 \quad{ }^{1} \mathrm{H}$ NMR see Table 1 and ${ }^{13} \mathrm{C}$ NMR see Table 2; HR-ESI-MS: $m / z 1211.37698[\mathrm{M}-\mathrm{H}]^{-}$(calcd. for

$2 \quad \mathrm{C}_{58} \mathrm{H}_{67} \mathrm{O}_{28}$ for 1271,38244$)$.

\subsubsection{Arundinoside $N(\mathbf{3})$ :}

White amorphous powder $(4.5 \mathrm{mg}) ;[\alpha]_{D}^{25}-58\left(c 0.2, \mathrm{CH}_{3} \mathrm{OH}\right) ; \mathrm{UV}\left(\mathrm{CH}_{3} \mathrm{OH}\right) \lambda_{\max }(\log \varepsilon): 219$ (3.11), 270 (1.95), 277 (1.92); IR: 3364, 1733, 1643, 1529, 1366, 1241, 1164, 1077, 820 and $715 \mathrm{~cm}^{-1}$; ${ }^{1} \mathrm{H}$ NMR see Table 1 and ${ }^{13} \mathrm{C}$ NMR see Table 2; HR-ESI-MS: $\mathrm{m} / \mathrm{z} 1211.37566[\mathrm{M}-\mathrm{H}]^{-}$(calcd. for $\mathrm{C}_{58} \mathrm{H}_{67} \mathrm{O}_{28}$ for 1271,38244$)$.

\subsubsection{Arundinoside $O(\mathbf{4 )}$ :}

White amorphous powder $(4.1 \mathrm{mg}) ;[\alpha]_{D}^{25}-71\left(c 0.2, \mathrm{CH}_{3} \mathrm{OH}\right) ; \mathrm{UV}\left(\mathrm{CH}_{3} \mathrm{OH}\right) \lambda_{\max }(\log \varepsilon): 218$ (3.04), 277 (1.82); IR 3337, 1762, 1630, 1570, 1571, 1355, 1207, 1143, 1049, 1022, 822 and $704 \mathrm{~cm}^{-1}$; ${ }^{1} \mathrm{H}$ NMR see Table 1 and ${ }^{13} \mathrm{C}$ NMR see Table 2; HR-ESI-MS: $m / z$ 1047.32844 [M-H] ${ }^{-}$(calcd. for $\mathrm{C}_{49} \mathrm{H}_{59} \mathrm{O}_{25}$ for 1047.33509).

\subsubsection{Arundinoside $P(\mathbf{5})$ :}

White amorphous powder (1.2 mg); $[\alpha]_{D}^{25}-93\left(c 0.2, \mathrm{CH}_{3} \mathrm{OH}\right) ; \mathrm{UV}\left(\mathrm{CH}_{3} \mathrm{OH}\right) \lambda_{\max }(\log \varepsilon): 222$ (3.06), 270 (2.02), 277 (1.95), 323 (1.84); IR 3345, 1731, 1619, 1515, 1372, 1226, 1160, 1061, 1036, 832 and $704 \mathrm{~cm}^{-1} ;{ }^{1} \mathrm{H}$ NMR see Table 1 and ${ }^{13} \mathrm{C}$ NMR see Table 2; HR-ESI-MS: $\mathrm{m} / z 1112.36172$ $[\mathrm{M}+\mathrm{NH} 4]^{+}$(calcd. for $\mathrm{C}_{54} \mathrm{H}_{68} \mathrm{NO}_{25}$ for 1130.40749).

\subsubsection{Arundinoside $Q(\mathbf{6})$ :}

White amorphous powder $(8.2 \mathrm{mg}) ;[\alpha]_{D}^{25}-79\left(c 0.4, \mathrm{CH}_{3} \mathrm{OH}\right) ; \mathrm{UV}\left(\mathrm{CH}_{3} \mathrm{OH}\right) \lambda_{\max }(\log \varepsilon): 217$ (3.07), 269 (2.12), 278 (1.90; IR 3340, 1732, 1625, 1522, 1370, 1229, 1164, 1061, 1044, 830 and 701 $\mathrm{cm}^{-1}{ }^{1} \mathrm{H}$ NMR see Table 1 and ${ }^{13} \mathrm{C}$ NMR see Table 2; HR-ESI-MS: $m / z$. $737.22886[\mathrm{M}-\mathrm{H}]^{-}$(calcd. for $\mathrm{C}_{34} \mathrm{H}_{41} \mathrm{O}_{18}$ for 737.23425$)$.

\subsection{Determination of the configuration of the sugar}

The configuration of the sugar moiety was determined according to the method of Simmler et al. [23]. The compound $(1 \mathrm{mg})$ was dissolved in $2 \mathrm{M} \mathrm{HCl}(0.5 \mathrm{~mL})$ and heated for 3 hours under reflux. The solution was cooled and partitioned three times with $n$-butanol. After partitioning, the aqueous phase was dried under reduced pressure and derivatization was performed with pyridine and 
1 1-(trimethylsilyl) imidazole $(4: 1 \mathrm{v} / \mathrm{v})$ at $60^{\circ} \mathrm{C}$ for 1 hour. The identification of the derivatized sample

2 was conducted on a GC-MS Trace GC Ultra instrument equipped with a TR-5MS SQC column $(0.25$ $3 \mu \mathrm{m}, 15 \mathrm{~m} \mathrm{x} 0.25 \mathrm{~mm}$ ) and operated using the following set of conditions: $1 \mathrm{~min}$ at $40^{\circ} \mathrm{C}$; a thermal 4 ramp of $10^{\circ} \mathrm{C}$ until $250^{\circ} \mathrm{C}$ (helium flow rate $1 \mathrm{~mL} / \mathrm{min}$, injector temperature $250^{\circ} \mathrm{C}$, transfer temperature $\left.285^{\circ} \mathrm{C}\right)$. The detection was performed on a DSQII Thermo Scientific mass spectrometer, with a detection mass range of $\mathrm{m} / \mathrm{z} 0$ to 500. The sugar (D-glucose) was identified based on the comparison of the retention time of the derivative with that of the standard glucose treated in the same manner.

\subsection{Determination of $\alpha$-glucosidase inhibitory activity}

The $\alpha$-glucosidase inhibitory activity was assessed based on previous report [24]. Stock solutions of samples were prepared at $10,000 \mu \mathrm{g} / \mathrm{mL}$ and diluted with $50 \mathrm{mM}$ phosphate buffer (pH 6.9) to concentration range of $0.1-5000 \mu \mathrm{g} / \mathrm{ml}$. The mixture composed of $50 \mu \mathrm{L}$ of the sample mixed $50 \mu \mathrm{L}$ of $\alpha$-glucosidase enzyme $(0.57 \mathrm{unit} / \mathrm{mL})$ was incubated in a shake-incubator at $37^{\circ} \mathrm{C}$ for 10 mins. Thereafter, $50 \mu \mathrm{L}$ of the substrate $p$-nitrophenyl $\alpha$-D- glucopyranoside $(5 \mathrm{mM})$ was added to the mixture and further incubated at $37^{\circ} \mathrm{C}$ for 20 mins. The reaction was halted by adding $50 \mu \mathrm{L}$ of $1 \mathrm{M}$ Sodium carbonate and the absorbance was determined at $405 \mathrm{~nm}$. Acarbose was used as a standard for comparison. $50 \mu \mathrm{L}$ of $50 \mathrm{mM}$ phosphate buffer ( $\mathrm{pH}$ 6.9) was used as the negative control. The concentration which inhibits $50 \%$ of $\alpha$-glucosidase $\left(\mathrm{IC}_{50}\right)$ was calculated from linear regression. Percentage inhibition was determined according to equation;

$$
\text { \%inhibition } \left.=\left[\mathrm{A}_{\mathrm{n}}-\left(\mathrm{A}_{\mathrm{s}}-\mathrm{A}_{\mathrm{bs}}\right) / \mathrm{A}_{\mathrm{n}}\right)\right] \times 100
$$

Where: $A_{n}=$ absorbance of negative solution (no sample)

$$
\mathrm{A}_{\mathrm{s}}=\text { absorbance of sample solution }
$$

$$
\mathrm{A}_{\mathrm{bs}}=\text { absorbance of blank sample solution }
$$

\subsection{DPPH scavenging assay}

The DPPH radical scavenging activity was evaluated using the method of Wong et al. [25]. Stock solutions of the sample and standard were prepared at $5000 \mu \mathrm{g} / \mathrm{mL}$ and diluted to two-folds $(1.22-2500 \mu \mathrm{g} / \mathrm{mL})$. Then $180 \mu \mathrm{L}$ of DPPH $(80 \mu \mathrm{M})$ was added to $20 \mu \mathrm{L}$ of portion of the sample in a 96-well plate. The mixture was kept in the dark at $25^{\circ} \mathrm{C}$ for 30 minutes. The absorbance was read at 
$1520 \mathrm{~nm}$. Trolox was used as the positive control. The DPPH radical scavenging activity of the samples

2 and standard was calculated thus;

$$
\text { Scavenging activity }(\%)=\frac{\left(\mathrm{OD}_{\text {control }}-\mathrm{OD}_{\text {sample }}\right) \times 100}{\mathrm{OD}_{\text {control }}}
$$

The concentration causing 50\% inhibition of DPPH radical $\left(\mathrm{IC}_{50} ; \mathrm{mg} / \mathrm{mL}\right)$ was determined graphically.

\subsection{ABTS scavenging assay}

The ABTS radical scavenging ability was performed as previously reported with some modifications [25]. Briefly, $2 \mathrm{mM}$ of ABTS and $2.45 \mathrm{mM}$ of potassium persulfate were mixed in equal proportion and the resulting mixture was incubated in the dark for 16 hours. The mixture was further diluted with phosphate buffer saline until the absorbance value was between 0.68 and 0.72 when measured at $734 \mathrm{~nm}$. The samples were serially diluted to a concentration range of $1.22-2500 \mu \mathrm{g} / \mathrm{mL}$ and $200 \mu \mathrm{L}$ of the ABTS solution was added to $20 \mu \mathrm{L}$ of the samples in a 96-wells plate. After 6 minutes the absorbance was read at $734 \mathrm{~nm}$. ABTS radical scavenging ability was calculated from the equation;

$$
\text { Scavenging activity }(\%)=\quad\left(\mathrm{OD}_{\text {control-OD }} \text { sample }\right) \times 100
$$

$$
\mathrm{OD}_{\text {control }}
$$

\section{Results and discussion}

The ethyl acetate extract from the underground parts of A. graminifolia was subjected to purification using various chromatographic techniques, namely centrifugal partition chromatography, gel permeation and reverse phase preparative chromatography leading to the isolation of six new compounds: arundinosides L-Q, along with five known compounds arundinosides D-F [20], J and K [21] (Fig. 1). 


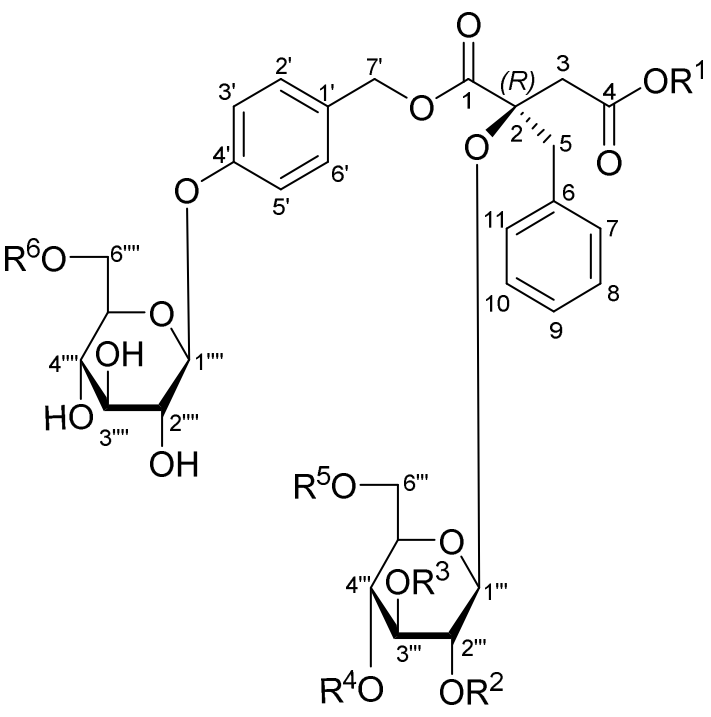

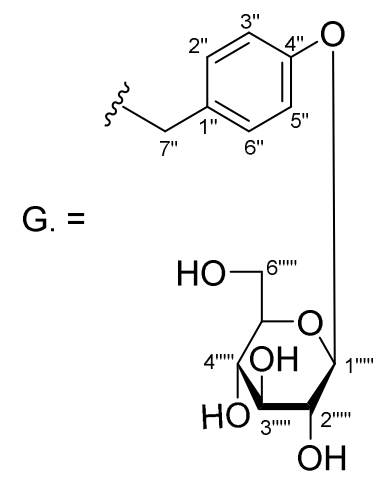

ß-D-glucopyranosyloxybenzyl<smiles></smiles>

$\mathrm{BM} .=$<smiles>CCC(=O)CC(C)(O)CC(=O)O</smiles>

$2 R$-benzylmalyl<smiles>[B]C=CCc1ccc(O)cc1</smiles>

4-Hydroxybenzyl

\begin{tabular}{|c|c|c|c|c|c|c|}
\hline & $\mathbf{R}^{\mathbf{1}}$ & $\mathbf{R}^{\mathbf{2}}$ & $\mathbf{R}^{\mathbf{3}}$ & $\mathbf{R}^{\mathbf{4}}$ & $\mathbf{R}^{\mathbf{5}}$ & $\mathbf{R}^{\mathbf{6}}$ \\
\hline Arundinoside L (1) & $\mathrm{G}$ & $\mathrm{Ac}$ & $\mathrm{H}$ & $\mathrm{H}$ & $\mathrm{BM}$ & $\mathrm{H}$ \\
\hline Arundinoside M (2) & $\mathrm{G}$ & $\mathrm{Ac}$ & $\mathrm{H}$ & $\mathrm{Ac}$ & $\mathrm{BM}$ & $\mathrm{H}$ \\
\hline Arundinoside N (3) & $\mathrm{G}$ & $\mathrm{Ac}$ & $\mathrm{Ac}$ & $\mathrm{H}$ & $\mathrm{BM}$ & $\mathrm{H}$ \\
\hline Arundinoside O (4) & $\mathrm{G}$ & $\mathrm{Ac}$ & $\mathrm{Ac}$ & $\mathrm{H}$ & $\mathrm{H}$ & $\mathrm{Ac}$ \\
\hline Arundinoside P (5) & $\mathrm{G}$ & $\mathrm{Ac}$ & $\mathrm{Ac}$ & $\mathrm{H}$ & $\mathrm{H}$ & $\mathrm{HB}$ \\
\hline Arundinoside Q (6) & $\mathrm{H}$ & $\mathrm{Ac}$ & $\mathrm{Ac}$ & $\mathrm{H}$ & $\mathrm{H}$ & $\mathrm{H}$ \\
\hline Arundinoside J (7) & $\mathrm{G}$ & $\mathrm{Ac}$ & $\mathrm{H}$ & $\mathrm{H}$ & $\mathrm{Ac}$ & $\mathrm{Ac}$ \\
\hline Arundinoside K (8) & $\mathrm{G}$ & $\mathrm{Ac}$ & $\mathrm{Ac}$ & $\mathrm{Ac}$ & $\mathrm{H}$ & $\mathrm{Ac}$ \\
\hline Arundinoside D (9) & $\mathrm{G}$ & $\mathrm{Ac}$ & $\mathrm{Ac}$ & $\mathrm{Ac}$ & $\mathrm{Ac}$ & $\mathrm{H}$ \\
\hline Arundinoside E (10) & $\mathrm{G}$ & $\mathrm{Ac}$ & $\mathrm{Ac}$ & $\mathrm{H}$ & $\mathrm{Ac}$ & $\mathrm{H}$ \\
\hline Arundinoside F (11) & $\mathrm{G}$ & $\mathrm{Ac}$ & $\mathrm{H}$ & $\mathrm{Ac}$ & $\mathrm{H}$ & $\mathrm{H}$ \\
\hline
\end{tabular}

4

5 Fig. 1. The chemical structures of the 11 acylated benzyl ester glucosides isolated from the

6 underground parts of A. graminifolia. 
Compound 1 was isolated as an optically active white amorphous powder $\left([\alpha]_{D}^{25}-56(c) 0.4\right.$,

$\left.2 \mathrm{CH}_{3} \mathrm{OH}\right)$ with a molecular formula of $\mathrm{C}_{56} \mathrm{H}_{66} \mathrm{O}_{7}$, based on the HR-ESI-MS (m/z 1169.36070, [M-H] $]^{-}$.

3 The UV spectrum displayed absorption maxima at 218 and $270 \mathrm{~nm}$. The acid hydrolysis of 1 yielded 4 glucose as the only sugar moiety as confirmed by GC-MS analysis [23]. The ${ }^{1} \mathrm{H}$ NMR spectrum of $\mathbf{1}$ (Table 1) displayed signals attributable to one acetyl group at $\delta_{\mathrm{H}} 1.76$ (2"'-Ac-2), four methylene groups at $\delta_{\mathrm{H}} 2.97(\mathrm{H}-3 \mathrm{a}), 3.07(\mathrm{H}-3 \mathrm{~b})$ and $3.02(\mathrm{H}-5 \mathrm{a}), 3.09(\mathrm{H}-5 \mathrm{~b}), \delta_{\mathrm{H}} 2.52$, (6"'-BM-3a), 2.97 (6"'BM-3b), $\delta_{\mathrm{H}} 2.85$ (6"'-BM-5a) and 2.97 (6"'-BM-5b); three anomeric protons at $\delta_{\mathrm{H}} 4.85(\mathrm{H}-1 " '), 4.93$ (H-1"'") and 4.93 (H-1"'"') ; two $\mathrm{A}_{2} \mathrm{~B}_{2}$ system at $\delta_{\mathrm{H}} 7.25$ (H-2'/6'), 7.09 (H-3'/5')] and $\delta_{\mathrm{H}} 7.29$ (H-2"/6"), $7.10(\mathrm{H}-3 " / 5 ")$ and two mono-substituted aromatic rings at $\delta_{\mathrm{H}} 7.05$ (H-7/11), 7.16 (H-8/10), 7.15 (H-9), 7.14 (6"'-BM-H-7/11), 7.21 (6"'-BM-H-8/10) and 7.15 (6"'-BM-H-9). The NMR spectra $\left({ }^{1} \mathrm{H}\right.$ and $\left.{ }^{13} \mathrm{C}\right)$ of $\mathbf{1}$ had a close resemblance to those of arundinoside C [20], possessing two benzylmalic acids, two hydroxybenzyl and three $\beta$-D-glucopyranosyl functionalities. The difference between compound $\mathbf{1}$ and arundinoside $\mathrm{C}$ was the absence of two acetyl groups at positions C-3"' and C-4"' in 1. This 2benzylmalic derivative obtained exhibited a negative optical rotation of powder $\left([\alpha]_{D}^{25}-56(c 0.4\right.$, $\mathrm{CH}_{3} \mathrm{OH}$ ), which is consistent with a $R$ absolute configuration and based on the biogenetic relationship as previously reported in the literature [20-21, 26-28]. Therefore we assigned compound $\mathbf{1}$ as 1,4 bis( $\beta$-D-glucopyranosyloxybenzyl)-2-( $\beta$-D-glucopyranosyl-2-acetyl-6->1-2R-benzylmalyl)-2Rbenzylmalic acid which was named arundinoside $\mathrm{L}$.

Compound 2 was isolated as a white amorphous powder and had a molecular formula of $\mathrm{C}_{58} \mathrm{H}_{68} \mathrm{O}_{28}$ based on the analysis of its HR-ESI-MS spectrum which displayed a $[\mathrm{M}-\mathrm{H}]^{-}$ion at $\mathrm{m} / \mathrm{z}$ 1211.37698. The acid hydrolysis of 2 liberated D-glucose which was identified with GC-MS. The NMR data $\left({ }^{1} \mathrm{H}\right.$ and ${ }^{13} \mathrm{C}$; Table 1 and 2) were closely identical to those of $\mathbf{1}$ with the exception of an additional acetyl group at position C-4"' in $2\left(\delta_{\mathrm{C}} 172.1, \delta_{\mathrm{C}} 21.3, \delta_{\mathrm{H}} 2.12\right)$. The acetyl group was assigned to C-4"' based on the HMBC correlations between H-4"'/C-4"'-Ac-1 and H-4"'-Ac-2/C-4"'Ac-1 (Fig. 2). The absolute configuration of 2 was deduced as $2 R$ in the same manner as done for compound 1. Thus, compound 2 was assigned as 1,4 bis-( $\beta$-D-glucopyranosyloxybenzyl)-2-( $\beta$-Dglucopyranosyl-2,4-diacetyl-6->1-2R-benzylmalyl)-2R-benzylmalic acid and further named arundinoside $\mathrm{M}$. 
2 ion peak at $m / z 1211.37566[\mathrm{M}-\mathrm{H}]^{-}$in the HR-ESI-MS spectrum. The 1D NMR spectra data of $\mathbf{3}$

3 (Tables 1 and 2) were very similar to those of compound 2, with the exception of the acetyl group at

4 C-4"' which was absent in 3 where it was replaced by an acetyl group at C-3"' $\left(\delta_{\mathrm{C}} 172.1 \mathrm{ppm}, \delta_{\mathrm{C}} 20.8\right.$

$\left.5 \mathrm{ppm}, \delta_{\mathrm{H}} 2.05 \mathrm{ppm}\right)$. Correlations from H-3"'/C-3"'-Ac-1 and H-3"'-Ac-2/C-3"'-Ac-1 as evidenced in the

6 HMBC spectrum confirmed the attachment of the acetyl group to C-3"' (Fig. 2). The absolute

7 configuration of $\mathbf{3}$ was determined by comparison of the negative optical rotation which was similar

8 with a $2 R$ absolute configuration with those of previous reports [20-21, 26-28]. Accordingly,

9 compound 3 was assigned as 1,4 bis-( $\beta$-D -glucopyranosyloxybenzyl)-2-( $\beta$-D-glucopyranosyl-2,3-

10 diacetyl-6->1-2R-benzylmalyl)-2R-benzylmalic acid and named arundinoside $\mathrm{N}$. 


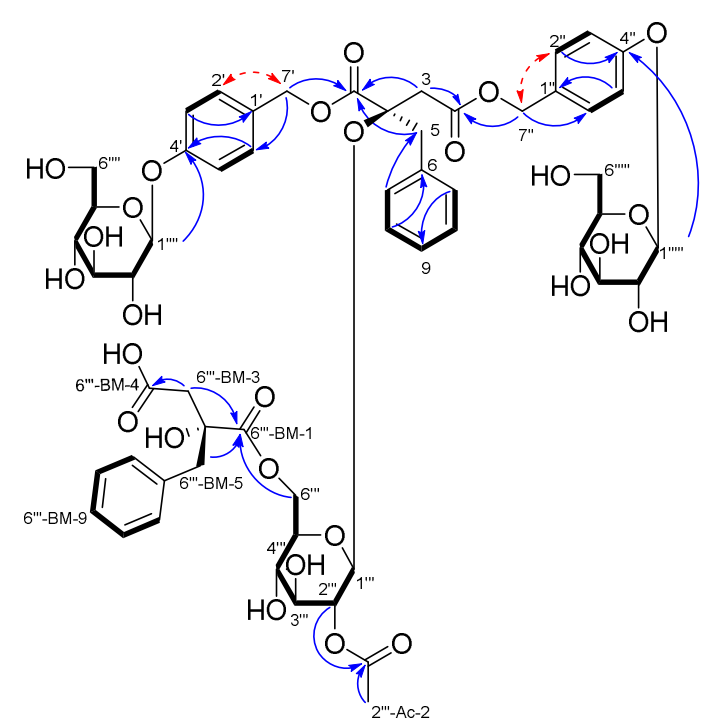

Arundinoside $\mathrm{H}$ (1)

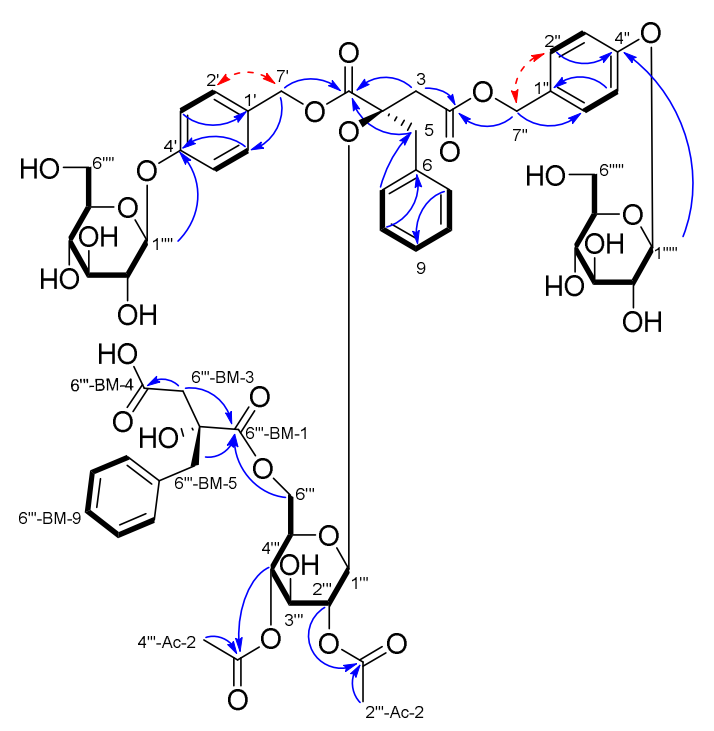

Arundinoside I (2)

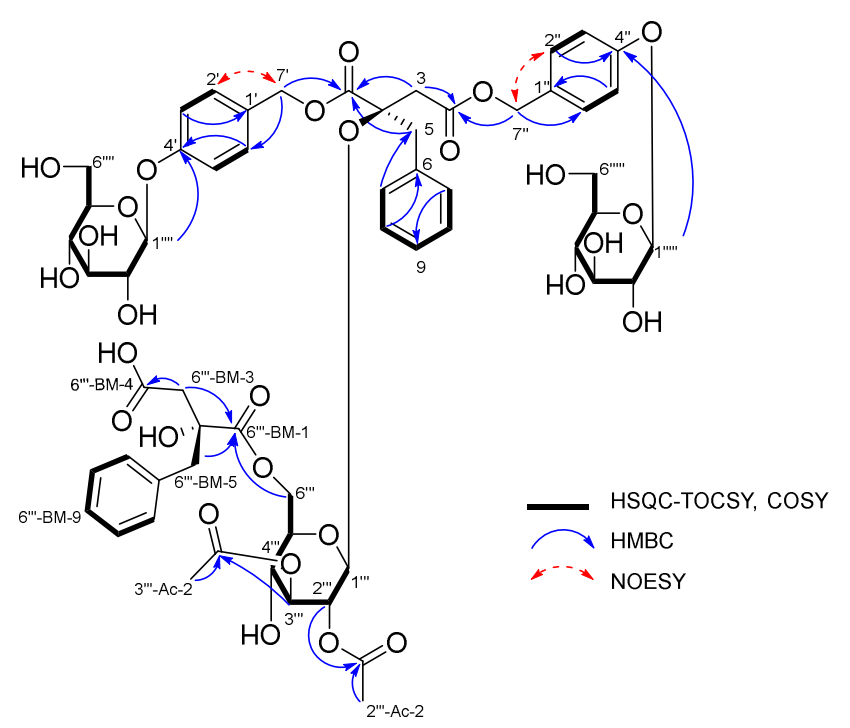

Arundinoside J (3)

Fig. 2. Key HSQC-TOCSY, COSY, HMBC and NOESY correlations of arundinosides L-N (1-3).

3

4

5

6

7

8 
Table 1.

$2 \quad{ }^{1} \mathrm{H}\left(500 \mathrm{MHz}\right.$, methanol- $\left.d_{4}\right)$ NMR data of arundinosides L-Q (1-6).

\begin{tabular}{|c|c|c|c|c|c|c|}
\hline Position & Arundinoside L (1) & Arundinoside M (2) & Arundinoside N (3) & Arundinoside O (4) & Arundinoside P (5) & Arundinoside Q (6) \\
\hline \multicolumn{7}{|l|}{1} \\
\hline \multicolumn{7}{|l|}{2} \\
\hline $3 a$ & $2.97(\mathrm{~d}, 17.9)$ & $2.99(\mathrm{~d}, 17.5)$ & $2.98(\mathrm{~d}, 17.5)$ & $3.12(\mathrm{~d}, 18.0)$ & $3.11(\mathrm{~d}, 17.9)$ & $3.03(\mathrm{~d}, 16.8)$ \\
\hline $3 b$ & $3.07(\mathrm{~d}, 17.9)$ & $3.11(\mathrm{~d}, 17.5)$ & $3.07(\mathrm{~d}, 17.5)$ & $3.16(\mathrm{~d}, 18.0)$ & $3.15(\mathrm{~d}, 17.9)$ & $3.13(\mathrm{~d}, 16.8)$ \\
\hline \multicolumn{7}{|l|}{4} \\
\hline $5 a$ & $3.02(\mathrm{~d}, 13.7)$ & $3.02(\mathrm{~d}, 13.7)$ & $3.02(\mathrm{~d}, 13.7)$ & $2.96(\mathrm{~d}, 13.6)$ & $2.96(\mathrm{~d}, 13.6)$ & $2.94(\mathrm{~d}, 13.6)$ \\
\hline $5 b$ & $3.09(\mathrm{~d}, 13.7)$ & $3.11(\mathrm{~d}, 13.7)$ & $3.09(\mathrm{~d}, 13.7)$ & $3.02(\mathrm{~d}, 13.6)$ & $3.02(\mathrm{~d}, 13.6)$ & $3.00(\mathrm{~d}, 13.6)$ \\
\hline \multicolumn{7}{|l|}{6} \\
\hline $7 / 11$ & $7.04-7.06(\mathrm{~m})$ & $7.04-7.06(\mathrm{~m})$ & $7.02-7.06(\mathrm{~m})$ & $7.01-7.03(\mathrm{~m})$ & $7.01-7.03(\mathrm{~m})$ & $7.02-7.04(\mathrm{~m})$ \\
\hline $8 / 10$ & $7.14-7.16(\mathrm{~m})$ & $7.15-7.18(\mathrm{~m})$ & $7.14-7.16(\mathrm{~m})$ & $7.13-7.17(\mathrm{~m})$ & $7.13-7.18(\mathrm{~m})$ & $7.14-7.18(\mathrm{~m})$ \\
\hline 9 & $7.14-7.16(\mathrm{~m})$ & $7.15-7.18(\mathrm{~m})$ & $7.14-7.16(\mathrm{~m}))$ & $7.13-7.17(\mathrm{~m})$ & $7.15-7.18(\mathrm{~m})$ & $7.15-7.17(\mathrm{~m})$ \\
\hline \multicolumn{7}{|l|}{$1^{\prime}$} \\
\hline $2^{\prime} / 6^{\prime}$ & $7.24(\mathrm{~d}, 8.7)$ & $7.25(\mathrm{~d}, 8.7)$ & $7.25(\mathrm{~d}, 8.5)$ & $7.24(\mathrm{~d}, 8.7)$ & $7.22(\mathrm{~d}, 8.7)$ & $7.27(\mathrm{~d}, 8.7)$ \\
\hline $3^{\prime} / 5^{\prime}$ & $7.09(\mathrm{~d}, 8.7)$ & $7.09(\mathrm{~d}, 8.7)$ & $7.10(\mathrm{~d}, 8.5)$ & $7.06(\mathrm{~d}, 8.7)$ & $7.08(\mathrm{~d}, 8.7)$ & $7.09(\mathrm{~d}, 8.7)$ \\
\hline
\end{tabular}




\begin{tabular}{|c|c|c|c|c|c|c|}
\hline $4^{\prime}$ & & & & & & \\
\hline $7 a^{\prime}$ & $4.95-4.98(\mathrm{~m})$ & $4.96(\mathrm{~d}, 11.8)$ & $4.96-4.98(\mathrm{~m})$ & $4.93-4.95(\mathrm{~m})$ & $4.96(\mathrm{~d}, 11.9)$ & $4.93-4.95(\mathrm{~m})$ \\
\hline $7 b^{\prime}$ & $5.02-5.05(\mathrm{~m})$ & $5.04(\mathrm{~d}, 11.8)$ & $5.05(\mathrm{~d}, 11.8)$ & $5.04(\mathrm{~d}, 11.9)$ & $5.03(\mathrm{~d}, 11.9)$ & $5.10(\mathrm{~d}, 12.0)$ \\
\hline \multicolumn{7}{|l|}{$1^{\prime \prime}$} \\
\hline $2^{\prime \prime} / 6^{\prime \prime}$ & $7.28(\mathrm{~d}, 8.7)$ & $7.29(\mathrm{~d}, 8.7)$ & $7.29(\mathrm{~d}, 8.5)$ & $7.29(\mathrm{~d}, 8.7)$ & $7.27(\mathrm{~d}, 8.6)$ & \\
\hline $3 " / 5^{\prime \prime}$ & $7.09(\mathrm{~d}, 8.7)$ & $7.10(\mathrm{~d}, 8.7)$ & $7.10(\mathrm{~d}, 8.5)$ & $7.09(\mathrm{~d}, 8.7)$ & $7.09(\mathrm{~d}, 8.6)$ & \\
\hline \multicolumn{7}{|l|}{$4^{\prime \prime}$} \\
\hline $7 a^{\prime \prime}$ & $4.91-4.93(\mathrm{~m})$ & $4.87-4.90(\mathrm{~m})$ & $4.91-4.93(\mathrm{~m})$ & $4.90-4.92(\mathrm{~m})$ & $4.89-4.92(\mathrm{~m})$ & \\
\hline $7 b^{\prime \prime}$ & $5.04-5.06(\mathrm{~m})$ & $5.07(\mathrm{~d}, 11.9)$ & $5.05(\mathrm{~d}, 11.8)$ & $5.07(\mathrm{~d}, 12.1)$ & $5.05(\mathrm{~d}, 11.7)$ & \\
\hline $2-O$-glc-1"' & $4.85(\mathrm{~d}, 8.0)$ & $4.92-4.94(\mathrm{~m})$ & $4.98-5.01(\mathrm{~m})$ & $5.10(\mathrm{~d}, 8.1)$ & $5.11(\mathrm{~d}, 8.0)$ & $5.13(\mathrm{~d}, 8.1)$ \\
\hline $2^{\prime \prime \prime}$ & $4.75(\mathrm{dd}, 8.0,9.3)$ & $4.81(\mathrm{dd}, 8.0,9.5)$ & $4.83(\mathrm{dd}, 8.0,9.5)$ & $4.78(\mathrm{dd}, 8.1,9.6)$ & $4.78(\mathrm{dd}, 8.0,9.3)$ & $4.80(\mathrm{dd}, 8.1,9.8)$ \\
\hline $3 " '$ & $3.36-3.38(\mathrm{~m})$ & $3.54(\mathrm{dd}, 9.5,9.5)$ & $4.91-4.95(\mathrm{~m})$ & $4.93-4.97(\mathrm{~m})$ & $4.93-4.97(\mathrm{~m})$ & $4.94-4.98(\mathrm{~m})$ \\
\hline $4 " '$ & $3.40-3.43(\mathrm{~m})$ & $4.85-4.90(\mathrm{~m})$ & $3.53(\mathrm{dd}, 9.5,9.5)$ & $3.59(\mathrm{dd}, 9.6 ; 9.6)$ & $3.58-3.61(\mathrm{~m})$ & $3.70(\mathrm{dd}, 9.5 ; 9.5)$ \\
\hline $5 " '$ & $3.08-3.10(\mathrm{~m})$ & $\begin{array}{c}3.22(\mathrm{ddd}, 2.2,4.5 \text {, } \\
9.5)\end{array}$ & $3.07-3.11(\mathrm{~m})$ & $2.94-2.98(\mathrm{~m})$ & $2.95-2.98(\mathrm{~m})$ & $3.07-3.11(\mathrm{~m})$ \\
\hline $6 a^{\prime \prime \prime}$ & $4.00(\mathrm{dd}, 4.4,11.7)$ & $3.81(\mathrm{dd}, 4.5,12.1)$ & $4.00(\mathrm{dd}, 3.8,11.9)$ & $3.46-3.49(\mathrm{~m})$ & $3.47-3.49(\mathrm{~m})$ & $3.71(\mathrm{dd}, 5.0 ; 11.9)$ \\
\hline 6b"' & $4.12(\mathrm{~d}, 11.7)$ & $4.02(\mathrm{dd}, 2.2,12.1)$ & $4.10(\mathrm{~d}, 11.9)$ & $3.55(\mathrm{dd}, 3.7,12.1)$ & $3.56(\mathrm{dd}, 3.8,12.1)$ & $3.78(\mathrm{dd}, 1.7 ; 11.9)$ \\
\hline
\end{tabular}




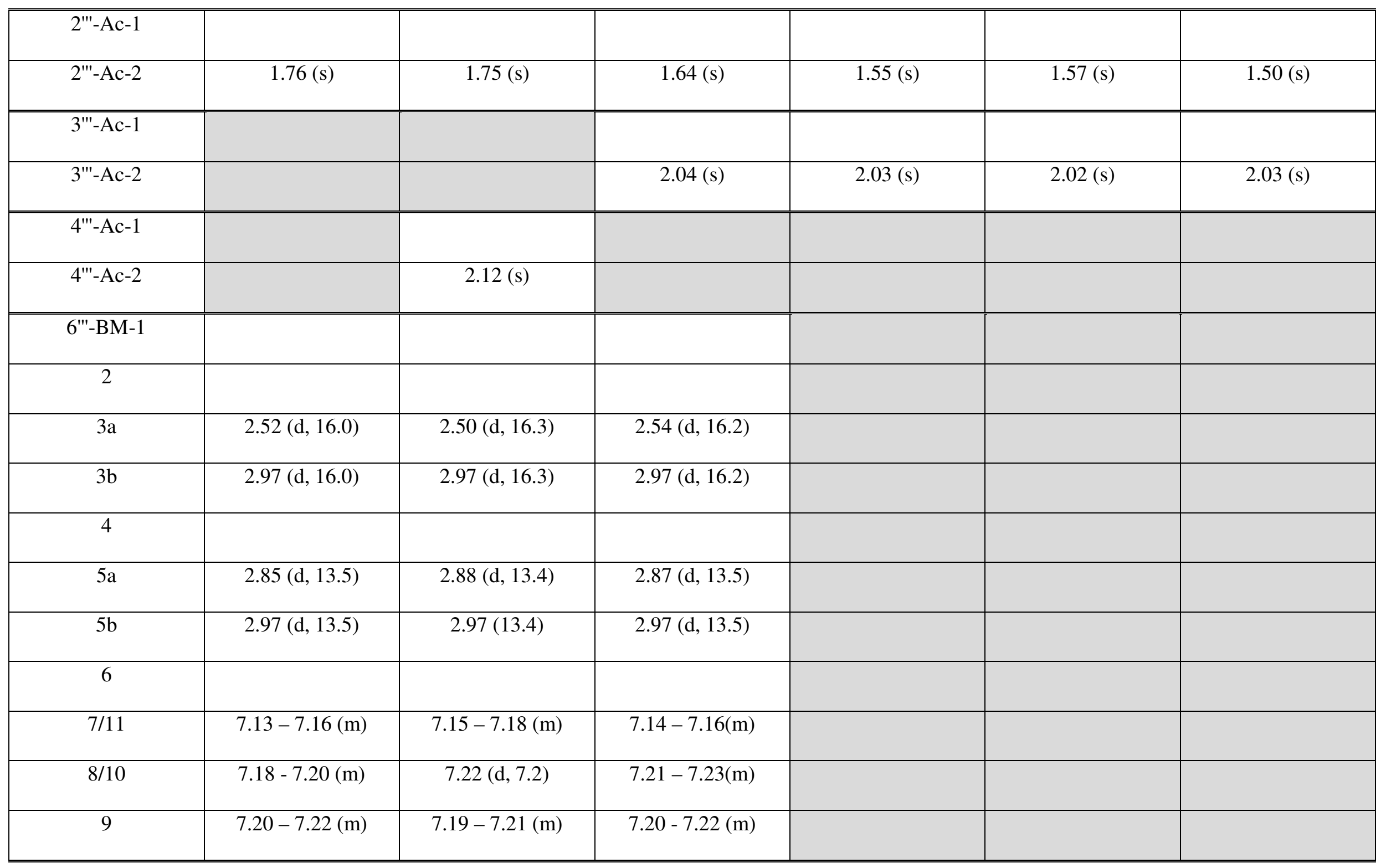




\begin{tabular}{|c|c|c|c|c|c|c|}
\hline $4^{\prime}-O-g l c-1^{\prime \prime \prime \prime}$ & $4.90-4.95(\mathrm{~m})$ & $4.89-4.91(\mathrm{~m})$ & $4.91-4.95(\mathrm{~m})$ & $4.91-4.95(\mathrm{~m})$ & $4.89-4.94(\mathrm{~m})$ & $4.91-4.95(\mathrm{~m})$ \\
\hline $2^{\prime \prime \prime \prime}$ & $3.47-3.50(\mathrm{~m})$ & $3.46-3.50(\mathrm{~m})$ & $3.46-3.49(\mathrm{~m})$ & $3.47-3.49(\mathrm{~m})$ & $3.44-3.50(\mathrm{~m})$ & $3.46-3.49(\mathrm{~m})$ \\
\hline $3^{\prime \prime \prime \prime}$ & $3.47-3.50(\mathrm{~m})$ & $3.46-3.50(\mathrm{~m})$ & $3.46-3.49(\mathrm{~m})$ & $3.46-3.50(\mathrm{~m})$ & $3.58-3.61(\mathrm{~m})$ & $3.45-3.50(\mathrm{~m})$ \\
\hline $4^{\prime \prime \prime \prime}$ & $3.40-3.43(\mathrm{~m})$ & $3.40-3.42(\mathrm{~m})$ & $3.39-3.42(\mathrm{~m})$ & $3.37-3.39(\mathrm{~m})$ & $3.36-3.40(\mathrm{~m})$ & $3.40-3.44(\mathrm{~m})$ \\
\hline $5^{\prime \prime \prime \prime}$ & $3.44-3.47(\mathrm{~m})$ & $3.43-3.45(\mathrm{~m})$ & $3.44-3.47(\mathrm{~m})$ & $3.63-3.67(\mathrm{~m})$ & $3.44-3.50(\mathrm{~m})$ & $3.42-3.46(\mathrm{~m})$ \\
\hline $6 a^{\prime \prime \prime \prime}$ & $3.89(\mathrm{dd}, 3.2,11.7)$ & $3.88(\mathrm{dd}, 2.0,12.1)$ & $3.89(\mathrm{~d}, 12.2)$ & $4.40(\mathrm{dd}, 2.2,12.1)$ & $3.59-3.63(\mathrm{~m})$ & $3.72(\mathrm{dd}, 5.0,11.8)$ \\
\hline $6 b^{\prime \prime \prime \prime}$ & $3.69-3.72(\mathrm{~m})$ & $3.71(\mathrm{dd}, 5.4,12.1)$ & $3.68-3.72(\mathrm{~m})$ & $4.24(\mathrm{dd}, 6.1,12.1)$ & $3.82-3.84(\mathrm{~m})$ & $3.90(\mathrm{dd}, 1.9,11.8)$ \\
\hline \multicolumn{7}{|l|}{ 6"'"-Ac-1 } \\
\hline 6"'"-Ac-2 & & & & $2.04(\mathrm{~s})$ & & \\
\hline \multicolumn{7}{|l|}{ 6"'"-G-1 } \\
\hline 6"'-G-G/6 & & & & & $7.13(\mathrm{~d}, 8.3)$ & \\
\hline 6"'--G-3/5 & & & & & $6.73(\mathrm{~d}, 8.3)$ & \\
\hline \multicolumn{7}{|l|}{6 "''-G-4 } \\
\hline 6"''-G-7a & & & & & $4.42(\mathrm{~d}, 11.3)$ & \\
\hline 6"'"-G-7b & & & & & $4.45(\mathrm{~d}, 11.3)$ & \\
\hline 4"-O-glc-1"'"' & $4.90-4.95(\mathrm{~m})$ & $4.91-4.93(\mathrm{~m})$ & $4.91-4.95(\mathrm{~m})$ & $4.91-4.95(\mathrm{~m})$ & $4.89-4.94(\mathrm{~m})$ & \\
\hline 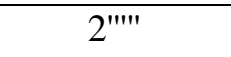 & $3.47-3.50(\mathrm{~m}))$ & $3.46-3.49(\mathrm{~m})$ & $3.44-3.47(\mathrm{~m})$ & $3.47-3.49(\mathrm{~m})$ & $3.44-3.50(\mathrm{~m})$ & \\
\hline
\end{tabular}




\begin{tabular}{|c|c|c|c|c|c|c|}
\hline $3^{\prime \prime \prime \prime}$ & $3.47-3.50(\mathrm{~m})$ & $3.46-3.50(\mathrm{~m})$ & $3.46-3.49(\mathrm{~m})$ & $3.46-3.50(\mathrm{~m})$ & $3.44-3.50(\mathrm{~m}))$ & $3.39-3.44(\mathrm{~m})$ \\
\hline $4 " '+\prime$ & $3.40-3.43(\mathrm{~m})$ & $3.40-3.42(\mathrm{~m})$ & $3.40-3.42(\mathrm{~m})$ & $3.40-3.42(\mathrm{~m})$ & $3.44-3.50(\mathrm{~m})$ & \\
\hline 5 "'"' & $3.44-3.47(\mathrm{~m}$ & $3.43-3.45(\mathrm{~m})$ & $3.44-3.47(\mathrm{~m})$ & $3.44-3.46(\mathrm{~m})$ & $3.70(\mathrm{dd}, 5.4,12.1)$ \\
\hline $6 a^{\prime \prime \prime \prime}$ & $3.89(\mathrm{dd}, 3.2,11.7)$ & $3.89(\mathrm{dd}, 2.0,12.1)$ & $3.89(\mathrm{~d}, 12.0)$ & $3.70(\mathrm{dd}, 5.4,12.1)$ & 3.70 \\
\hline $6 b^{\prime \prime \prime \prime}$ & $3.69-3.72(\mathrm{~m})$ & $3.69(\mathrm{dd}, 5.4,12.1)$ & $4.91-4.95(\mathrm{~m})$ & $3.89(\mathrm{dd}, 2.1,12.1)$ & $3.89(\mathrm{dd}, 2.0,12.1)$ \\
\hline
\end{tabular}

3 Table 2.

${ }^{13} \mathrm{C}\left(125 \mathrm{MHz}\right.$, methanol- $\left.d_{4}\right)$ NMR data of arundinosides L-Q (1-6). 


\begin{tabular}{|c|c|c|c|c|c|c|}
\hline Position & Arundinoside L (1) & Arundinoside M (2) & Arundinoside N (3) & Arundinoside O (4) & Arundinoside P (5) & Arundinoside Q (6) \\
\hline 1 & 172.2 & 172.2 & 172.2 & 172.4 & 172.4 & 172.8 \\
\hline 2 & 82.5 & 82.6 & 82.6 & 82.3 & 82.3 & 82.4 \\
\hline 3 & 43.0 & 43.2 & 43.2 & 44.0 & 44.1 & 44.5 \\
\hline 4 & 172.0 & 172.0 & 171.9 & 172.2 & 172.2 & 174.2 \\
\hline 5 & 46.0 & 46.2 & 46.3 & 47.3 & 47.3 & 47.4 \\
\hline 6 & 136.5 & 136.5 & 136.5 & 136.4 & 136.4 & 136.5 \\
\hline $7 / 11$ & 132.0 & 131.8 & 131.8 & 132.0 & 132.0 & 132.0 \\
\hline $8 / 10$ & 129.2 & 129.2 & 129.0 & 129.1 & 129.1 & 129.0 \\
\hline 9 & 128.0 & 128.0 & 127.9 & 127.9 & 128.0 & 127.9 \\
\hline $1^{\prime}$ & 130.8 & 130.8 & 130.6 & 130.9 & 131.2 & 130.8 \\
\hline $2^{\prime} / 6^{\prime}$ & 131.7 & 131.8 & 131.6 & 131.8 & 131.7 & 131.6 \\
\hline $3^{\prime} / 5^{\prime}$ & 118.0 & 118.0 & 117.9 & 117.9 & 118.1 & 117.8 \\
\hline $4^{\prime}$ & 159.4 & 159.4 & 159.5 & 159.2 & 159.4 & 159.3 \\
\hline $7^{\prime}$ & 68.0 & 68.0 & 68.1 & 68.0 & 68.0 & 68.0 \\
\hline
\end{tabular}




\begin{tabular}{|c|c|c|c|c|c|c|}
\hline $1^{\prime \prime}$ & 131.1 & 131.1 & 130.9 & 131.2 & 131.2 & \\
\hline $2^{\prime \prime} / 6^{\prime \prime}$ & 131.7 & 131.8 & 131.6 & 131.5 & 131.5 & \\
\hline $3 " / 5^{\prime \prime}$ & 118.1 & 118.0 & 118.1 & 118.0 & 118.0 & \\
\hline $4^{\prime \prime}$ & 159.4 & 159.4 & 159.5 & 159.4 & 159.3 & \\
\hline $7^{\prime \prime}$ & 67.5 & 67.5 & 67.6 & 67.5 & 67.5 & \\
\hline 2-O-glc-1"' & 98.6 & 98.5 & 98.4 & 98.5 & 98.5 & 98.6 \\
\hline $2 " '$ & 74.8 & 75.0 & 72.7 & 73.0 & 73.1 & 73.0 \\
\hline 3"' & 75.8 & 73.7 & 76.4 & 77.0 & 77.0 & 77.1 \\
\hline $4 " '$ & 71.0 & 71.8 & 68.9 & 68.9 & 69.0 & 71.4 \\
\hline $5 " '$ & 75.0 & 72.6 & 74.6 & 77.2 & 77.3 & 77.2 \\
\hline $6 a^{\prime \prime \prime}$ & 65.0 & 64.4 & 64.7 & 61.6 & 61.6 & 61.3 \\
\hline 2"'-Ac-1 & 172.4 & 172.2 & 171.8 & 172.0 & 172.1 & 172.1 \\
\hline 2"'-Ac-2 & 21.4 & 21.3 & 21.0 & 21.0 & 20.9 & 21.0 \\
\hline 3"'-Ac-1 & & & 172.1 & 172.2 & 172.2 & 172.3 \\
\hline 3"'-Ac-2 & & & 21.0 & 21.0 & 20.8 & 21.0 \\
\hline
\end{tabular}




\begin{tabular}{|c|c|c|c|c|c|c|}
\hline 4"'-Ac-1 & & 172.1 & & & & \\
\hline 4"'-Ac-2 & & 21.2 & & & & \\
\hline 6"'-BM-1 & 175.5 & 175.6 & 175.6 & & & \\
\hline 2 & 77.6 & 77.3 & 77.4 & & & \\
\hline 3 & 44.5 & 44.3 & 44.4 & & & \\
\hline 4 & 174.6 & 174.8 & 174.5 & & & \\
\hline 5 & 46.4 & 46.1 & 46.3 & & & \\
\hline 6 & 136.8 & 136.9 & 136.8 & & & \\
\hline $7 / 11$ & 132.0 & 131.8 & 131.6 & & & \\
\hline $8 / 10$ & 129.3 & 129.2 & 129.2 & & & \\
\hline 9 & 128.0 & 128.0 & 127.9 & & & \\
\hline $4^{\prime}-O-g l c-1^{\prime \prime \prime \prime}$ & 102.3 & 102.4 & 102.4 & 102.2 & 102.3 & 102.4 \\
\hline $2^{\prime \prime \prime \prime}$ & 75.0 & 75.0 & 74.9 & 75.0 & 75.0 & 75.0 \\
\hline $3^{\prime \prime \prime \prime}$ & 78.0 & 78.0 & 77.8 & 77.8 & 77.2 & 78.0 \\
\hline $4^{\prime \prime \prime \prime}$ & 71.4 & 71.4 & 71.3 & 71.6 & 71.8 & 71.4 \\
\hline
\end{tabular}




\begin{tabular}{|c|c|c|c|c|c|c|}
\hline $5^{\prime \prime \prime \prime}$ & 78.2 & 78.2 & 78.0 & 75.4 & 78.1 & 78.2 \\
\hline $6^{\prime \prime \prime \prime}$ & 62.6 & 62.6 & 62.6 & 64.8 & 70.5 & 62.5 \\
\hline 6"'"-Ac-1 & & & & 172.9 & & \\
\hline 6"'"-Ac-2 & & & & 21.0 & & \\
\hline 6"'"-G-1 & & & & & 130.5 & \\
\hline 6"'"-G-2/6 & & & & & 130.8 & \\
\hline 6"'"-G-3/5 & & & & & 116.2 & \\
\hline 6"'"-G-4 & & & & & 158.3 & \\
\hline 6"'--G-7 & & & & & 74.5 & \\
\hline $4 "-O$-glc-1"'"'" & 102.2 & 102.3 & 102.4 & 102.3 & 102.3 & \\
\hline $2^{\prime \prime \prime \prime}$ & 75.0 & 75.0 & 74.9 & 75.0 & 75.0 & \\
\hline $3^{\prime \prime \prime \prime \prime}$ & 78.0 & 78.0 & 77.8 & 78.0 & 78.1 & \\
\hline $4 " ' "$ & 71.5 & 71.4 & 71.3 & 71.4 & 71.5 & \\
\hline $5 " ' " \prime$ & 78.2 & 78.2 & 78.0 & 78.2 & 78.2 & \\
\hline 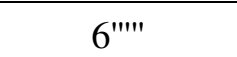 & 62.6 & 62.6 & 62.6 & 62.6 & 62.6 & \\
\hline
\end{tabular}


2 The molecular formula of compound 4 was assigned to be $\mathrm{C}_{49} \mathrm{H}_{60} \mathrm{O}_{25}$ based on the $[\mathrm{M}-\mathrm{H}]^{-}$ion peak at

$3 \mathrm{~m} / \mathrm{z}$ 1047.32844. The molecular formula of 4 was observed to be the same with compound 7, a

4 previously reported compound name arundinoside J [21]. The 1D NMR spectroscopic data of 4 (Table

$5 \quad 1$ and 2) were similar with those of arundinoside $\mathbf{J}$ (compound 7 [21]), which implied the presence of a

6 glucosyloxybenzyl $2 R$-benzylmalate derivative with three acetyl groups. The detailed analysis of the

$7 \quad$ NMR spectra indicated that the acetoxy moiety at C-6"' in arundinoside $\mathrm{J}$ was replaced by a hydroxyl

8 in 4, while the acetoxy moiety was at position C-3"'. This substitution pattern was affirmed by HMBC

9 cross-peak of H-3"' to C-3"'-Ac-1, which confirmed that the acetoxy group was attached to C-3"'

10 (Figure 3). The absolute configuration of 4 was also deduced as $2 R$ by comparison of the optical

11 rotation which was similar with a $2 R$ absolute configuration as previous reports [20-21, 26-28].

12 Compound 4 was therefore assigned as 1-( $\beta$-D-glucopyranosyloxybenzyl)-2-( $\beta$-D-glucopyranosyl-2,3-

13 biacetyl)-4-( $\beta$-D-glucopyranosyloxybenzyl-6-acetyl)-2R-benzylmalate and named arundinoside $\mathrm{O}$.

14

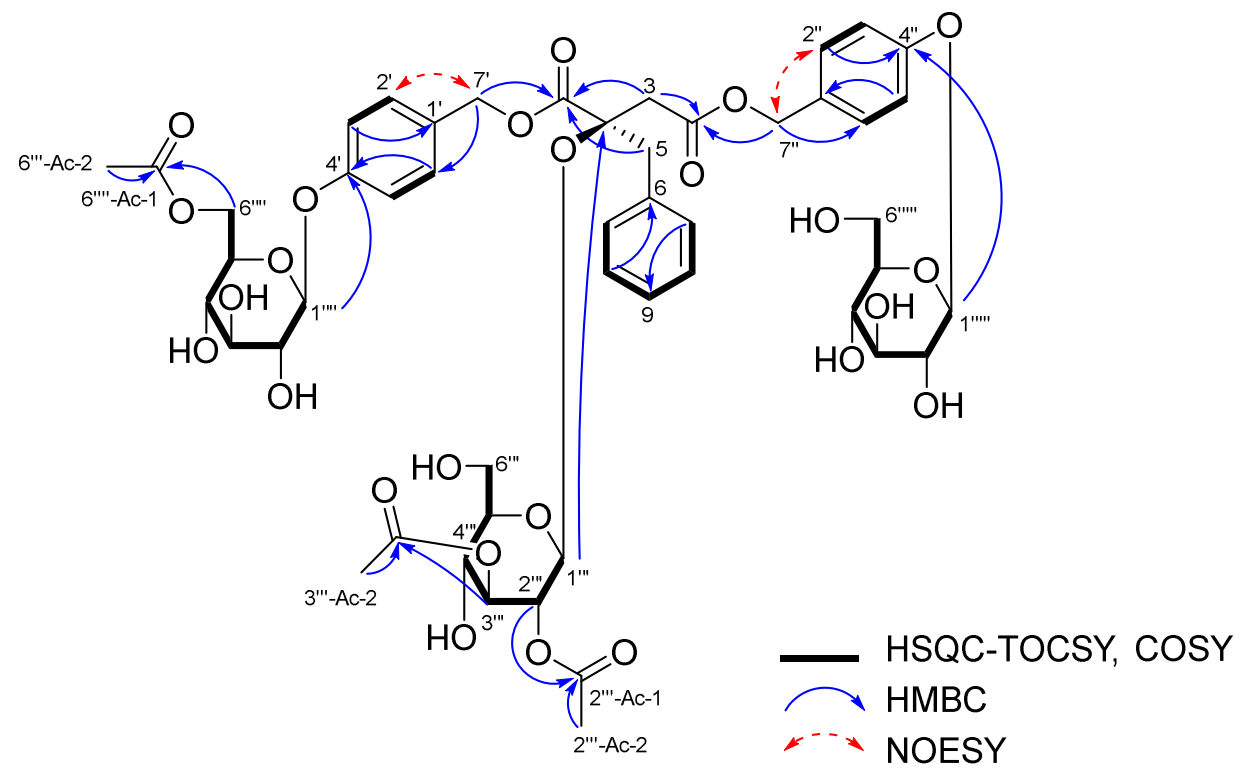

Fig. 3. Key HSQC-TOCSY, COSY, HMBC and NOESY correlations of arundinosides $\mathbf{O}$ (4).

Compound 5 was obtained as a white amorphous powder. It showed a molecular ion peak at $m / z 1130.40617\left[\mathrm{M}+\mathrm{NH}_{4}\right]^{+}$in the HR-ESI-MS, suggesting a molecular formula of $\mathrm{C}_{54} \mathrm{H}_{64} \mathrm{O}_{25}$. Detailed analysis of the NMR data of $\mathbf{5}$, indicated structural similarities between $\mathbf{5}$ and compounds $\mathbf{4}$, suggesting the presence of the 2-benzylmalic acid, benzyl- $\beta$-D-glucopyranoside , $\beta$-D-glucopyranoside and acetyl moieties. The major difference in $\mathbf{5}$ was the presence of an hydroxybenzyl moiety in C-6"' 
$\left[\delta_{\mathrm{H}} 7.13, \mathrm{H}-6\right.$ "'--G-2/6 and 6.73, H-6"'--G-3/5)]; [ $\delta_{\mathrm{C}} 130.5,130.8,116.2$ and 158.3$]$. HMBC correlations of $\mathrm{H}_{2}-6$ "'b with $\mathrm{C}-6$ '"'-G-7 as well as $\mathrm{H}_{2}-6$ "'"-G-7 with $\mathrm{C}-6$ 6"'-G-2/6 confirmed the presence and position of the hydroxybenzyl unit (Fig. 4). The absolute configuration of 5 was also deduced as $2 R$ by comparing the optical rotation which was similar with a $2 R$ absolute configuration with previous reports [20-21, 26-28] .Therefore, compound 5 was deduced as 1-( $\beta$-D-glucopyranosyloxybenzyl)-2( $\beta$-D-glucopyranosyl-2,3-diacetyl)-4-( $\beta$-D-glucopyranosyloxybenzyl-6-hydroxybenzyl)-2Rbenzylmalate and named arundinoside P.

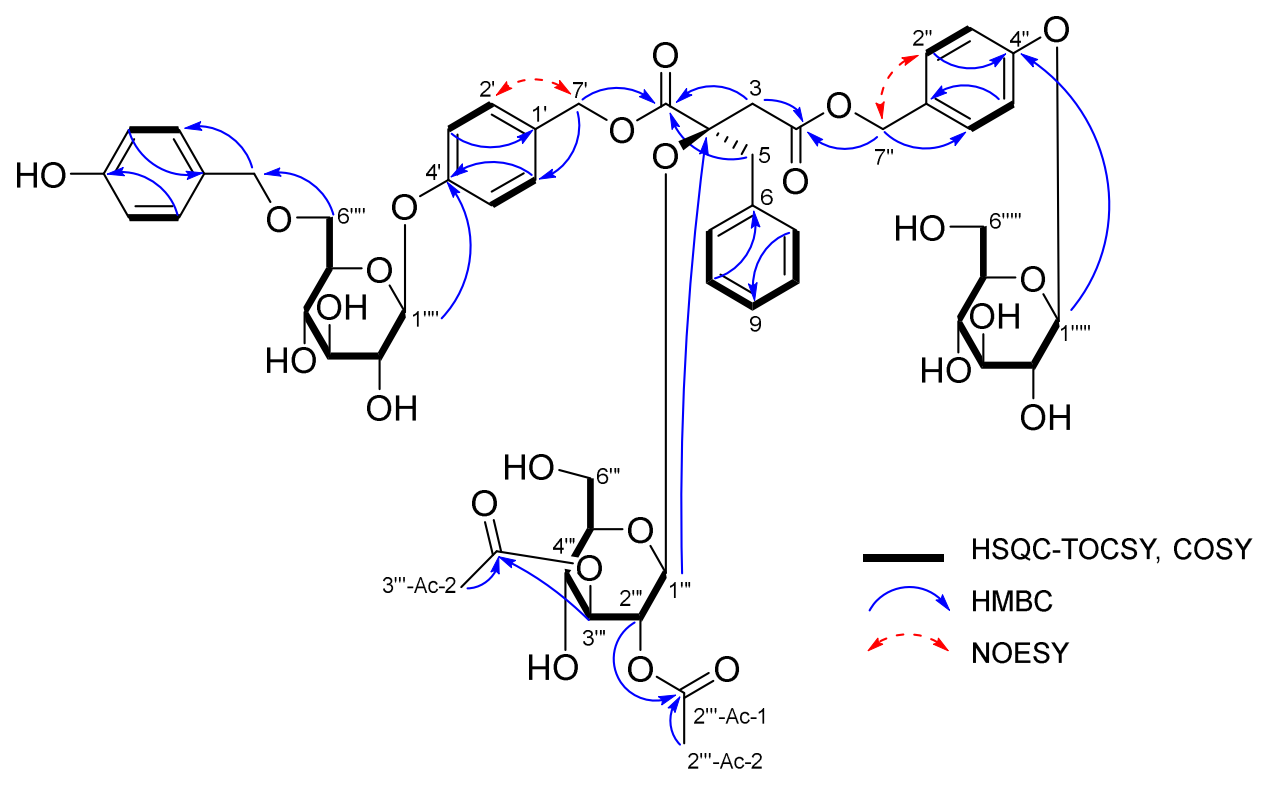

Fig. 4. Key HSQC-TOCSY, COSY, HMBC and NOESY correlations of arundinoside P (5).

Compound $\mathbf{6}$ was obtained as a white amorphous powder with a molecular formula of $\mathrm{C}_{34} \mathrm{H}_{42} \mathrm{O}_{18}$ as deduced on the basis of the positive HR-ESI-MS $\left(\mathrm{m} / \mathrm{z} 737.22886[\mathrm{M}-\mathrm{H}]^{-}\right)$. The ${ }^{1} \mathrm{H}$ NMR (Table 1) of 6 remarkably similar to those of the known arundinoside E (compound 10) [20], displaying signals of the 2-benzylmalic acid $\left[\delta_{\mathrm{H}} 7.03(\mathrm{H}-7 / 11), 7.16(8 / 10), 7.27\left(\mathrm{H}-2^{\prime} / 6^{\prime}\right), 7.09\right.$ (H$\left.2^{\prime} / 6^{\prime}\right), 5.10\left(\mathrm{H}^{\left.-7 b^{\prime}\right),} 4.95\left(\mathrm{H}-7 \mathrm{a}^{\prime}\right), 3.13(\mathrm{H}-3 \mathrm{~b}), 3.03(\mathrm{H}-3 \mathrm{a})\right]$, the $\beta$-D-glucopyranosyl moieties connected to C-2 of the benzylmalic acid [ $\delta_{\mathrm{H}} 5.13$ (H-1"'), 4.80 (H-2"'), 4.96 (H-3"'), 3.70 (H-4"'), 3.09 (H-5"'), 3.71 (H-6a"'), 3.78 (H-6b"')], one gluosyloxybenzyl moiety connected to C-2 [4.93 (H-1"''), 3.48 (H-2'"'), 3.47 (H-3'"'), 3.42 (H-4"''), 3.45 (H-5"''), 3.72 (H-6a'"'), 3.90 (H-6b"'')] and two acetyl groups at $\delta_{\mathrm{H}} 1.50(2 " '-\mathrm{Ac}-2)$ and $\delta_{\mathrm{H}} 2.03$ (3"'-Ac-2). The acetyl groups were positioned with the help of the HMBC cross peaks between cross-peak of H-2"' to C-2"'-Ac-1 and H-3"' to C-3"'-Ac-1. The 
gluosyloxybenzyl moiety connected to C-4 in arundinoside E was replaced by a hydroxyl group in 6 (Fig. 5). The absolute configuration of 6 was determined as $2 R$ by comparing its negative optical rotation which was similar with a $2 R$ absolute configuration with previous reports [20-21, 26-28]. Therefore, the structure of compound 6 was identified as 1-( $\beta$-D-glucopyranosyloxybenzyl)-2-( $\beta$-Dglucopyranosyl-2,3-diacetyl-2R-benzylmalate and named arundinoside Q.

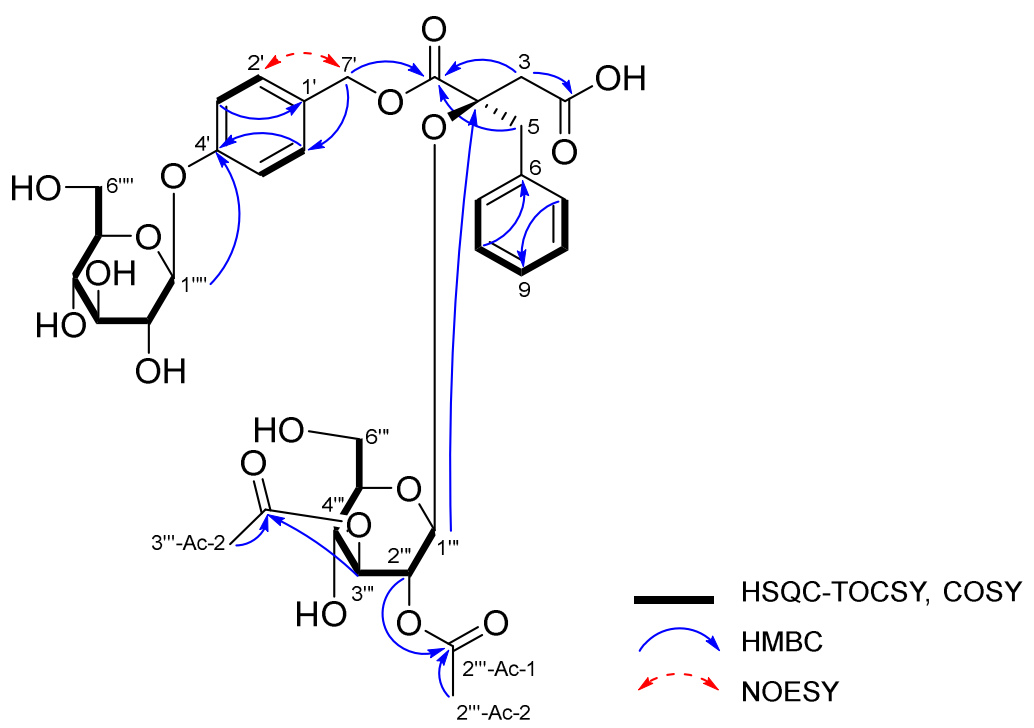

Fig. 5. Key HSQC-TOCSY, COSY, HMBC and NOESY correlations of arundinoside Q (6). $\alpha$-Alkylmalate ester derivatives are rather uncommon secondary metabolites which have been reported in the family Cephalotaxaceae as alkylmalate alkaloids [29] and Orchidaceae as benzylmalate alkaloids derivatives [30, 31], hydroxybenzyl [23], benzyl [32,33], or isobutylmalates ester glucosides derivatives $[34,35]$. Till date, glucosyloxybenzyl $2 R$-benzylmalate derivatives a have only been exclusively found in the Orchidaceae family, especially in terrestrial orchids from the genus Coeloglossum [33], Cremastra [36], Cymbidium [37-38], Grammatophyllum [26], and recently in Arundina [20-21]. These compounds are structurally arranged in a very specific manner, with at least one benzylmalic acid, which will serves as a central pillar to which the other biosynthetic parts are attached. One to two hydroxybenzyl moieties (gastrodigenin) esterified to the acidic function of the benzylmalic acid and a D-glucose in its pyranose form, is the only sugar reported till date in the structures of these glycosides. Glucosylation occurs on the free hydroxyl groups of gastrodigenin and the benzylmalic acid at position $\mathrm{C}-2$ on the structure. Furthermore, cinnamoyl, acetyl and 
benzylmaloyl moieties can be added to the basic functions described above by esterification on the

hydroxyl group of the sugar.

The isolated compounds were subjected to $\alpha$-glucosidase inhibitory activity as well as DPPH and ABTS radical scavenging activities. Arundinosides D, O, P and Q exhibited moderate $\alpha$ glucosidase inhibitory ( $\mathrm{IC}_{50}$ values of $159.74,22.06,18.24$ and $90.22 \mu \mathrm{g} / \mathrm{mL}$, respectively), ABTS radical scavenging $\left(\mathrm{IC}_{50}\right.$ values of $4.98,4.40,2.96$, and $6.75 \mu \mathrm{L} / \mathrm{mL}$, respectively) activities.

In conclusion, six new glucosyloxybenzyl $2 R$-benzylmalate derivatives, arundinosides L-Q (16) along with 5 known glucosides arundinosides D-F, J and K (7-11) were isolated for the first time from the underground part of A. graminifolia. Their structures were elucidated based on extensive spectroscopic data analysis. The structural novelty of arundinoside P, carrying a hydroxybenzyl moiety attached to the hydroxybenzylglucose moiety is a new kind of acylation, which has never been reported for this kind of compound. Furthermore, arundinoside $\mathrm{Q}$ is the first bidesmosidic derivative reported in A. graminifolia.

\section{Acknowledgements}

The authors wish to thank the French Ministry of Research and Education for the $\mathrm{PhD}$ scholarship offered to Florence Auberon. Also, this study was financially supported by Guerlain and LVMH Recherche. We appreciate the help of Mr. Maurice Coppé (Department of Chemistry, Strasbourg University) for the NMR experiments.

\section{Conflict of interest}

No competing interest declared

\section{A. Supplementary data}

Supplementary data associated with this article can be found on online at

\section{References}

[1] M.W. Chase, K.M. Cameron, J.V. Freudenstein, A.M. Pridgeon, G. Salazar, C. Berg, A. Schuiteman, An updated classification of Orchidaceae, Bot. J. Lin. Soc. 177(2) (2015) 151-174.

[2] D.Y. Hong, Y.S. Lian, L.D. Shen, Flora of China, Chinese Science Press, Beijing, China, 1983. 
90 of Dai indigenous medicine, on enhanced liver detoxification, J. Trad. Chin. Med. 35(2) (2015) 197-

91205.

92 [4] C. Zhang, V. Chongsuvivatwong, N. Keawpradub, Y. Lin, Analysis of prescription database 93 extracted from standard textbooks of traditional Dai medicine, J. Ethnobiol Ethnomed. 8 (2012) 34.

94 [5] G. Seidenfaden, A collection of orchids from Malaya, Nord. J. Bot. 6(2) (1986) 157-181.

[6] S. Deva, H.B. Naithani, The orchid flora of north-west Himalaya, New Delhi: Print and Media 96 Associates 1986, p. 459.

97 [7] N. Sugiura, Pollination and floral ecology of Arundina graminifolia (Orchidaceae) at the 98 northern border of the species' natural distribution, J. Plant Res. 127(1) (2014) 131-139.

99 [8] S.S. Fernando, P. Ormerod, An annotated checklist of the orchids of Sri Lanka, Rheedea 18(1) $100 \quad$ (2008) 1-28.

101 [9] M. Kolanowska, K. Konowalik, Niche conservatism and future changes in the potential area coverage of Arundina graminifolia, an invasive orchid species from Southeast Asia, Biotropica 46(2) 103 (2014) 157-165.

104 [10] M.M. Hossain, Traditional therapeutic uses of some indigenous orchids of Bangladesh, Med 105 Aromat Plant Sci Biotechnol 42(1) (2009) 101-106.

106 [11] Y. Gao, Y. Jin, S. Yang, J. Wu, X. Gao, Q. Hu, Y. Ma, A new diphenylethylene from 107 Arundina graminifolia and its cytotoxicity, Asian J. Chem. 26(13) (2014) 3903-3905.

108 [12] Y.-K. Li, B. Zhou, Y.-Q. Ye, G. Du, D.-Y. Niu, C.-Y. Meng, X.-M. Gao, Q.-F. Hu, Two new 109 diphenylethylenes from Arundina graminifolia and their cytotoxicity, Bull. Korean Chem. Soc. 34(11) $110 \quad$ (2013) 3257-3260.

111 [13] P.L. Majumder, S. Ghosal, Two stilbenoids from the orchid Arundina bambusifolia, 112 Phytochemistry 32(2) (1993) 439-444.

113 [14] G. Du, Y. Shen, L. Yang, L. Shu, M.-L. Wen, Q.-F. Hu, Bibenzyl Derivatives of Arundina 114 graminifolia and their Cytotoxicity, Chem. Nat. Compd. 49(6) (2014) 1019-1022.

115 [15] M.F. Liu, Y. Han, D.M. Xing, W. Wang, L.Z. Xu, L.J. Du, Y. Ding, One new 116 benzyldihydrophenanthrene from Arundina graminifolia, J Asian Nat Prod Res 7(5) (2005) 767-70. 
118 extrusion Counter-current Chromatography Separation of Two New Benzyl Ester Glucosides and

119 Three Other High-polarity Compounds from the Tubers of Pleione bulbocodioides, Phytochem. Anal.

$120 \quad 24(6)(2013) 671-676$.

121 [17] Q.F. Hu, B. Zhou, J.M. Huang, X.M. Gao, L.D. Shu, G.Y. Yang, C.T. Che, Antiviral phenolic compounds from Arundina gramnifolia, J Nat Prod 76(2) (2013) 292-6. graminifolia and their anti-tobacco mosaic virus activity, Bull. Korean Chem. Soc. 33(7) (2012) 2447-

\section{9.}

126 [19] D.-Y. Niu, J.-M. Han, W.-S. Kong, Z.-W. Cui, Q.-F. Hu, X.-M. Gao, Antiviral fluorenone 127 derivatives from Arundina gramnifolia, Asian J. Chem. 25(17) (2013) 9514-9516.

128 [20] F. Auberon, O.J. Olatunji, S. Krisa, G. Herbette, C. Antheaume, F. Bonte, J.-M. Merillon, A. 129 Lobstein, Arundinosides A-G, new glucosyloxybenzyl $2 R$-benzylmalate derivatives from the aerial 130 parts of Arundina graminifolia, Fitoterapia 125 (2018) 199-207.

131 [21] Q. Liu, F. Sun, Y. Deng, R. Dai, F. Lv, HPLC-ESI-MS(n) Identification and NMR

132 Characterization of Glucosyloxybenzyl 2R-Benzylmalate Derivatives from Arundina Graminifolia and

133 Their Anti-Liver Fibrotic Effects In Vitro, Molecules 24(3) (2019).

134 [22] F. Auberon, O.J. Olatunji, S. Krisa, C. Antheaume, G. Herbette, F. Bonte, J.-M. Merillon, A. 135 Lobstein, Two new stilbenoids from the aerial parts of Arundina graminifolia (Orchidaceae), 136 Molecules 21(11) (2016) 1430/1-1430/9.

137 [23] C. Simmler, C. Antheaume, P. Andre, F. Bonte, A. Lobstein, Glucosyloxybenzyl eucomate 138 derivatives from Vanda teres stimulate HaCaT cytochrome c oxidase, J. Nat. Prod. 74(5) (2011) 949139955.

140 [24] S. Kumar, V. Kumar, O. Prakash, Enzymes inhibition and antidiabetic effect of isolated 141 constituents from Dillenia indica. Biomed Res Int. 2013;1-7

142 [25] F.C. Wong, A.L. Yong, E.P. Ting, S.C. Khoo, H.C. Ong, T.T. Chai, Antioxidant, 143 metalchelating, anti-glucosidase activities and phytochemical analysis of selectedtropical medicinal 144 plants. Iran J Pharm Res. 2014;13(4):1409-1415 
146 Glucopyranosyloxybenzyl derivatives of $(R)$-2-benzylmalic acid and $(R)$-eucomic acid, and an

147 aromatic glucoside from the pseudobulbs of Grammatophyllum speciosum, Tetrahedron 69(3) (2013)

$148 \quad 1031-1037$.

149 [27] T. Tanaka, H. Suda, H. Naganawa, M. Hamada, T. Takeuchi, T. Aoyagi, H. Umezawa, 150 Production of $(S)$ - a -benzylmalic acid, inhibitor of carboxypeptidase A by actinomycetes, J. Antibiot. $151 \quad 37(6)(1984) 682-4$.

152 [28] S.A.A. El Bialy, H. Braun, L.F. Tietze, Enantioselective synthesis of $\alpha$-alkylmalates as the 153 pharmacophoric group of several natural alkaloids and glycosides, Eur. J. Org. Chem. (14) (2005) $154 \quad 2965-2972$

155 [29] H. Abdelkafi, B. Nay, Natural products from Cephalotaxus sp.: chemical diversity and 156 synthetic aspects, Nat. Prod. Reports 29(8) (2012) 845-869.

157 [30] B. Luning, H. Trankner, S. Brandange, Orchidaceae alkaloids. V. A new alkaloid from 158 Phalaenopsis amabilis, Acta Chem. Scand. 20(7) (1966) 2011.

159 [31] 2 S. Brandange, B. Luning, C. Moberg, E. Sjostrand, Orchidaceae alkaloids. XXIV. 160 Pyrrolizidine alkaloid from Phalaenopsis cornu-cervi, Acta Chem. Scand. 25(1) (1971) 349-50.

161 [32] Wang, S.-H. Guan, Y.-H. Meng, Y.-B. Zhang, C.-R. Cheng, Y.-Y. Shi, R.-H. Feng, F. Zeng, 162 Z.-Y. Wu, J.-X. Zhang, M. Yang, X. Liu, Q. Li, X.-H. Chen, K.-S. Bi, D.-A. Guo, Phenanthrenes, 163 9,10-dihydrophenanthrenes, bibenzyls with their derivatives, and malate or tartrate benzyl ester 164 glucosides from tubers of Cremastra appendiculata, Phytochemistry 94 (2013) 268-276.

165 [33] S.-Y. Huang, G.-Q. Li, J.-G. Shi, S.-Y. Mo, S.-J. Wang, Y.-C. Yang, Chemical constituents of 166 the rhizomes of Coeloglossum viride var. bracteatum, J. Asian Nat. Prod. Res. 6(1) (2004) 49-61.

167 [34] H. Kizu, E.-I. Kaneko, T. Tomimori, Studies on nepalese crude drugs. XXVI. Chemical 168 constituents of panch aunle, the roots of Dactylorhiza hatagirea D. don, Chem. Pharm. Bull. 47(11) 169 (1999) 1618-1625.

170 [35] B.B. Cota, A. Magalhaes, A.M.C. Pimenta, E.P. Siqueira, T.M.A. Alves, C.L. Zani, Chemical 171 constituents of Habenaria petalodes Lindl. (Orchidaceae), J. Braz. Chem. Soc. 19(6) (2008) 1098$172 \quad 1104$. 
173 [36] Y. Wang, S.-H. Guan, Y.-H. Meng, Y.-B. Zhang, C.-R. Cheng, Y.-Y. Shi, R.-H. Feng, F.

174 Zeng, Z.-Y. Wu, J.-X. Zhang, M. Yang, X. Liu, Q. Li, X.-H. Chen, K.-S. Bi, D.-A. Guo,

175 Phenanthrenes, 9,10-dihydrophenanthrenes, bibenzyls with their derivatives, and malate or tartrate

176 benzyl ester glucosides from tubers of Cremastra appendiculata, Phytochemistry 94 (2013) 268-276.

177 [37] K. Yoshikawa, M. Okahuji, K. Iseki, T. Ito, Y. Asakawa, S. Kawano, T. Hashimoto, Two

178 novel aromatic glucosides, marylaurencinosides D and E, from the fresh flowers of Cymbidium Great

179 Flower 'Marylaurencin', J. Nat. Med. 68(2) (2014) 455-458

180 [38] K. Yoshikawa, M. Otsu, T. Ito, Y. Asakawa, S. Kawano, T. Hashimoto, Aromatic constituents

181 of Cymbidium Great Flower Marie Laurencin and their antioxidative activity, J. Nat. Med. 67(1)

182 (2013) 217-221. 


\section{Arundinosides L-Q}

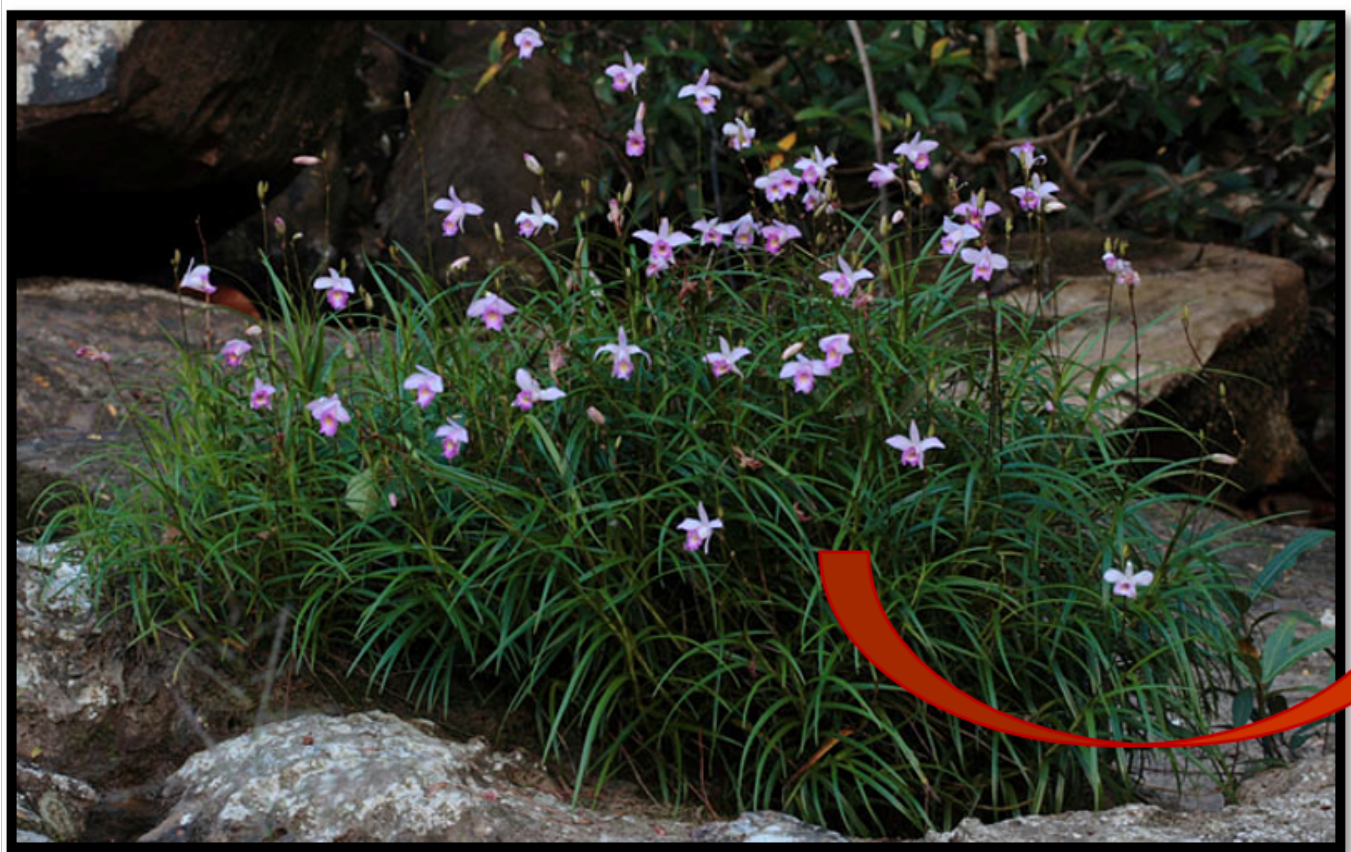

Dried Underground Parts of the tropical orchid Arundina graminifolia (D.Don) Hochr.
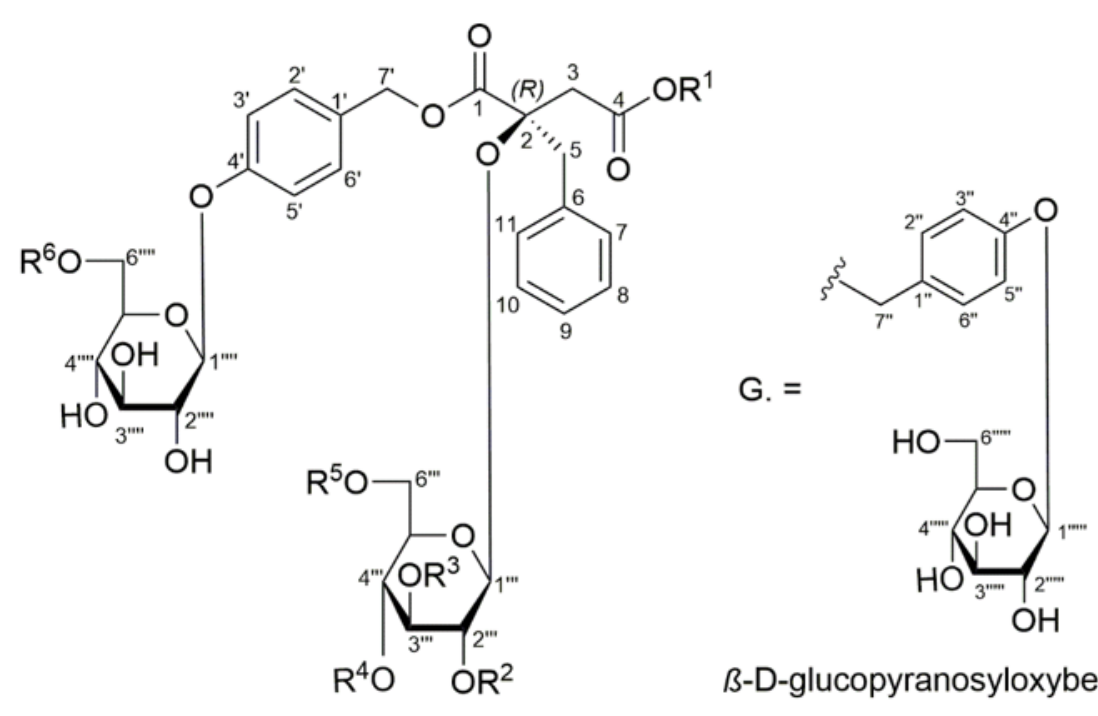

B-D-glucopyranosyloxybenzyl

Arundinoside L (1)

Arundinoside M (2)

Arundinoside N (3)

Arundinoside $\mathrm{O}(4)$

Arundinoside $P(5)$

Arundinoside $Q(6)$

$\mathrm{R}^{1}$

$\mathbf{R}^{2}$

AC

Ac

$A c$

Ac
$A c=$ ह $\mathrm{CH}_{3}$ acetyl

$\mathrm{BM}$. =<smiles>CC(=O)C(O)(CC(=O)O)Cc1ccccc1</smiles>

2R-benzylmalyl

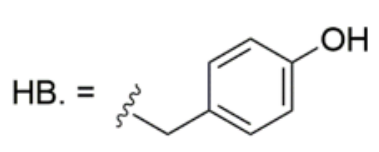

4-Hydroxybenzyl

\begin{tabular}{cc}
$\mathbf{R}^{\mathbf{5}}$ & $\mathbf{R}^{\mathbf{6}}$ \\
\hline BM. & $\mathrm{H}$ \\
BM. & $\mathrm{H}$ \\
BM. & $\mathrm{H}$ \\
$\mathrm{H}$ & $\mathrm{AC}$ \\
$\mathrm{H}$ & $\mathrm{HB}$ \\
$\mathrm{H}$ & $\mathrm{H}$
\end{tabular}

